\title{
House prices and macroeconomic implications. Current knowledge
}

\author{
Michael White \\ Nottingham Trent University, UK \\ Paloma Taltavull de La Paz \\ University of Alicante, Spain
}

\begin{abstract}
This paper contains a summary of the literature to frame and understand the reasons why the EU regulations such as the Macroeconomic Imbalance Procedure (MIP) and the Excessive Imbalance Procedure (EIP) include changes in house prices as one of the 14 indicators of economic imbalances. It also discusses whether or not that indicator needs to be complemented to follow housing market dynamics. The paper explains how the housing market is related to real as well as financial markets and how, through the channels of transmission, house prices define the house price channel linking financial shocks with real shocks and create imbalances. A classification of imbalances is also provided in the literature discussed below.
\end{abstract}

Keywords: housing, macroeconomy, economic imbalances.

JEL classification: R11, R13, R31.

\section{Resumen}

Este artículo presenta un resumen de la literatura que ayuda a enmarcar y comprender las razones por las que la regulación de la UE ha incluido el crecimiento de los precios de las viviendas como uno de los indicadores de la Macroeconomic Imbalance Procedure (MIP) y de la Excessive Imbalance Procedure (EIP). El artículo desarrolla la idea de la necesidad de que ese indicador sea complementado con otros para que capture con coherencia la evolución de la dinámica de los mercados residenciales. El artículo explica como se relacionan los mercados de viviendas con los financieros y también cómo, a través de los canales de transmisión, los precios de las viviendas definen un canal propio que relaciona los cambios en los mercados financieros con los shocks reales y generan desequilibrios. Se relacionan, también, las tipologías de desequilibrios existentes con relación a los mercados de vivienda.

Palabras clave: vivienda, macroeconomía, desequilibrios económicos.

Clasificación JEL: R11, R13, R31.

\section{Introduction}

The Global Financial Crisis (GFC) and the ensuing credit crunch has had asymmetric impacts across European countries. However, common effects, notably the application of austerity policy measures, have prevailed with differing degrees of intensity and pace of activity among different countries. Greece and Ireland could be seen as two extremes in this regards. The Greek economy has continued to struggle 
throughout 2015 while in contrast, Ireland has experienced strong economic growth and falling unemployment, albeit after large emigration flows.

Differences in the capacity to recover and the rate at which this is taking place is variable raising issues pertaining to macroeconomic differences, institutional dissimilarities and a lack of convergence. The GFC has highlighted imbalances in Europe with potential consequences for integration in relation to aspects of the economy and social structure. The lack of harmonisation in, for example, the fiscal system, financial supervision, and differences in state welfare programmes has been well documented. However, some market mechanisms that are central to macroeconomic equilibrium, linking the financial system and real economy at the macro level, have received comparatively less attention. Of these the housing sector is fundamental with many analysts placing housing debt at the origins of the GFC. Indeed, housing imbalances and the operation of the housing market have been at the core of wider macroeconomic imbalances in several European countries. Several indicators clearly highlight the impact of housing:

- house price is a key factor impacting on household wealth;

- house prices affect the risk levels of financial institutions through the value of collateral for mortgages and real estate assets;

- house prices affect monetary policy objectives impacting inflation through the liquidity mechanism;

- the supply of new housing is a key determinant of economic growth and contributes $4 \%$ of real GDP on average over the long term;

- investment in real estate including housing accounts for around $15 \%$ of the total GDP in European countries;

- construction, including housing development, is a key economic sector with multiplier effects on other productive sectors with direct impacts on employment (income effect);

- the homeowner market impacts on consumption through the wealth effect.

Significantly, house prices and their impact on macroeconomic equilibrium has been recognized by the European Commission (EC) through the inclusion of house price indices as one of 14 scoreboard indicators chosen as «the most relevant dimensions of macroeconomic imbalances and competitiveness losses» (EU, 2012:41'). Likewise, the Macroeconomic Imbalance Procedure (MIP) and the Excessive Imbalance Procedure (EIP) identify change in house prices as the key early warning measure alerting to a possible macroeconomic imbalance as «...large movements in real asset markets have been traditionally associated with a number of economic crises...» (EU, 2012:16).

${ }^{1}$ European Economy (2012), «Scoreboard for the surveillance of macroeconomic imbalances», Occasional Papers 92, Brussels. Originally, there were 10 scoreboard indicators, the number increasing to 14 in 2015. 
Literature on housing markets shows how it is not only the prices that could generate economic imbalances although house prices would be the transmission tool. Several mechanisms exist through which housing dynamics (transactions, construction and prices) affect the economy. Providing a comprehensive explanation of them is not straightforward given the disparate literature.

The basic mechanism through which the housing market has macroeconomic effects is explained in diagram 1. As housing (and real estate in general) development has multiplier effects on total economic activity, any increase/decrease in construction has subsequent impacts on total GDP lasting more than one period, and acting as an acceleration/deceleration mechanism for the whole economy.

\section{DIAGRAM 1}

\section{CIRCULAR EFFECTS BETWEEN THE HOMEOWNERSHIP MARKET AND THE MACRO ECONOMY}

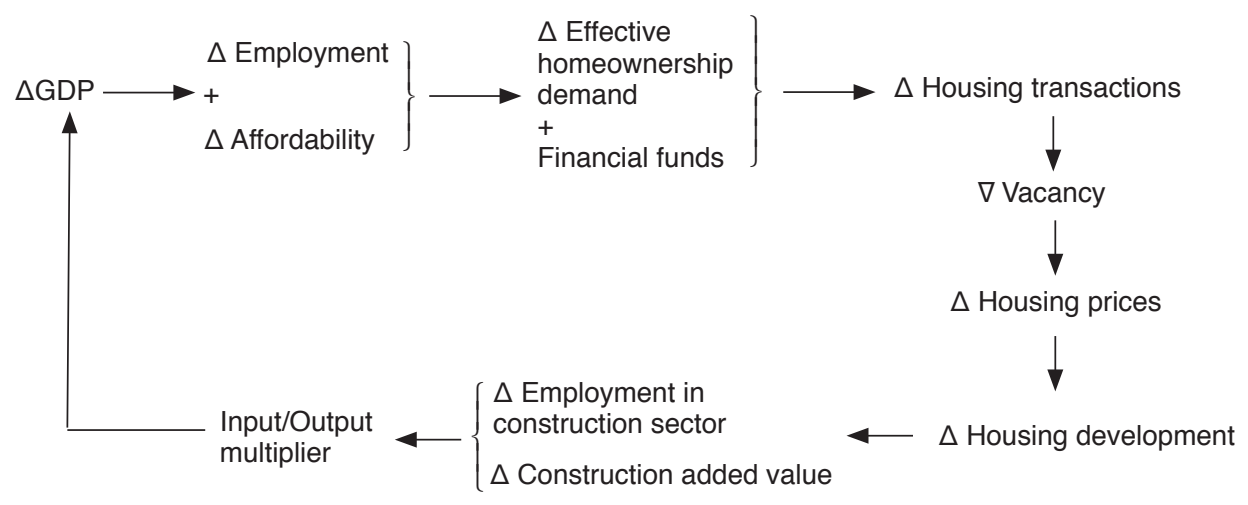

The economy also determines the strength of housing demand as a function of economic growth, job creation and/or wage levels, determining affordability for households and their capacity to express their demand in the housing market. Any increase in employment levels should occur together with an increase in household affordability affecting the housing market mechanism; low wages would not increase the effective demand ${ }^{2}$. In the homeowner market, the financial sector plays a key role funding households for housing purchases. If the flow of funds is enough, then housing transactions take place and the housing market mechanism causes an increase in house building, depending on the supply conditions in each local market.

Furthermore, there is a social (long term) mechanism linking housing markets and social equilibrium given that housing is one of the basic needs of the population, its

\footnotetext{
${ }^{2}$ It should happen when income elasticity of house prices is not elastic. In cases with elastic house price responses to increase on income, any increase on employment together with affordability could not be transformed into real housing demand.
} 
affordability and the ability to access housing of a reasonable standard has major social impacts, with effects in terms of homelessness, excessive debt, household formation, migration, labour market mobility and the functioning of the macroeconomy. Yet housing markets are often out of equilibrium with certain countries (e.g., the UK, Ireland, Spain) subject to booms and busts. While market information flows may have improved, the efficiency of the housing market is still debatable. The literature highlights that housing markets do not reach equilibrium in the short run resulting in alternate periods of bubbles and undersupply followed by periods of stagnant markets and few transactions. Likewise the ability to move between tenures is constrained in an inefficient market, with the ability to provide new supply in the social and affordable housing sectors also constrained, by the magnitude of the debt burden facing national administrations and local authorities (the latter is exemplified by problems facing municipalities in the Netherlands). These imbalances produce not only social hardship but also impact on the functioning of the macroeconomy through a variety of means, centred on the labour market with issues such as the ability of key-workers to access suitable housing.

Imbalances in housing markets can be investigated by first understanding the bidirectional relationships between the macroeconomy and housing markets, using a much wider set of indicators than is currently the case. In this respect, a weakness in the MIP framework is the assumption that the complexity of the housing market can be captured through a single measurement - namely the house price index growth rate. It is necessary to consider the impact of several indicators, including liquidity, mortgage risk, affordability, supply elasticity, loan to value ratios and other related variables.

Given the centrality of housing to the macroeconomy and the ability of the housing market to produce imbalances in the macroeconomy, this paper is specifically concerned with the relationships between the macroeconomy and housing market and focuses on the transmissions mechanisms that exist between and connect them. The paper seeks to articulate these relationships, with identification, estimation and quantification of the effects of an imbalance in the housing market and its impact on the economy at the macro level. Local development forms an integral part of this analysis, as impacts vary not only between countries, but are also differentiated within countries with uneven effects at regional and local geographies. Indeed, changes in demographics, including migration flows, have impacted on housing markets heterogeneously across regions and countries. The economic, financial and policy interventions stemming from these imbalances are central ingredients of this paper and frame the context of our subsequent discussion.

We examine the interaction between the housing market, the financial sector, and the macroeconomy. We find that income and mortgage flows have caused house price appreciation, interacting with migration flows. These variables are found to have difference levels of significance in different countries. Hence the relationship between the housing market and the macroeconomy is not always the same in different countries and it is important to understand how the relationship differs in order to make sensible policy recommendations, as one size does not fit all. 
The paper is structured as follows: the next section discusses the literature that reviews the financial crisis and the role argued to have been played by housing. The third section considers the specific transmission channels between the housing market and the macroeconomy. Section four provides a comparison across countries making policy recommendations. Section five discusses issues arising from the research and avenues for future work. Section six concludes.

\section{Literature review}

House prices witnessed a period of significant increases from the mid 1990s until 2007. Since then house prices fell in most Western economies, including the US, Ireland, Spain, Denmark and the UK. This has been followed by price increases particularly, for example, in the UK and Sweden, the latter being little affected by the GFC. Movement in house prices out of certain limits are a signal of imbalance, and it is generally accepted that imbalances in housing markets are a function of house price volatility. However, the housing market is considered as the one creating imbalances due to its lack of equilibrium not only in relation to price but also in relation to quantity (DiPasquale and Wheaton, 1996).

The complexity of the current crisis and the strong impacts at all levels requires detailed analysis based on the role played by different sectors. How the crisis' transmission occurred across EU countries, its effects, the strength of the credit crunch in different countries and consequences at a social level still raise many questions. While the literature explains how the financial crisis impacted on economies, the posterior impacts, the Central banks' reactions to avoid the worst of the effects and the recommended policies, there still remains a gap in the knowledge base as to how global effects contributed to macroeconomic imbalances.

\section{Endogenous imbalances}

Diagram 1 summarized the current and accepted relationships which would produce macroeconomic imbalances through house price responses. In economic modelling of housing markets, authors normally consider the demand and supply sides of the (owner-occupied) market. Housing demand is normally seen to be affected by the price of housing, population (permanent) income, wealth and financial funds available in the housing market (i.e., mortgages). Demand for housing may also depend upon the expected capital gain on housing. Higher capital gains reduce ownership cost and funds will flow to house purchase particularly within deregulated financial systems. The first way is well documented as the general response to the housing market mechanism (DiPasquale and Wheaton, 1994).

House price movements reflect short and long term factors. Long term economic growth driving real disposable income, while demographic and life style changes 
have a more gradual impact on demand for housing. In the short term prices may diverge from their long run trend, equilibrium, or fundamental values. Identifying this fundamental value has been a key debate in the literature (see Himmelberg et al., 2005). This is important because a rapid and/or prolonged price rise may not result in houses becoming overpriced if the adjustment is simply a response to correcting a previous imbalance that caused prices to fall below their fundamental values. Similarly, observing prices at any point in time does not mean that fundamental prices are being observed. More likely, the price being observed will deviate positively or negatively from its fundamental value.

When variables relating to demographics, finance or income change, the macroeconomic imbalance is transmitted to the housing market through their effects on the demand side, as shown in diagram 2. In homeowner markets, sudden changes in demand (such as external shocks in migration or finance) affect house prices generating a potential imbalance with additional effects due to the relationships that house prices have with other macroeconomic sectors. An example is when unexpected demand increases housing capital gains over other asset returns raising short term investment flows into housing market. The short term character of these flows could develop into price bubbles. Imbalances potentially appear when the demand is weak and prices do not grow reducing investment flows.

If local supply conditions allow house building, an increase in prices acts as a trigger for development which increases economic added value, with multiplier effects on the whole economy (Mueller, 1999). On the other hand, an increase in house prices rises household wealth, thereby increasing the role of housing as collateral for loans and modifies relative price expectations, with effects on affordability. Case and Quigley (2008) examine the reversal of housing booms and explore wealth, income, and financial market effects. They argue that housing wealth will have an impact on consumption especially as financial deregulation has permitted equity withdrawal from (increasingly valuable) housing assets. Thus higher house prices increase wealth and increase consumers' expenditure. However the authors argue that falling house prices are unlikely to lead to symmetric reductions in consumption expenditure. They further argue that consumption is also less likely to fall since house prices are sticky downwards and will fall less (in nominal terms) than they have increased.

The strength of change in house prices could create an incentive for extra investment in the housing market while a fall in house prices could cause the opposite reaction. 


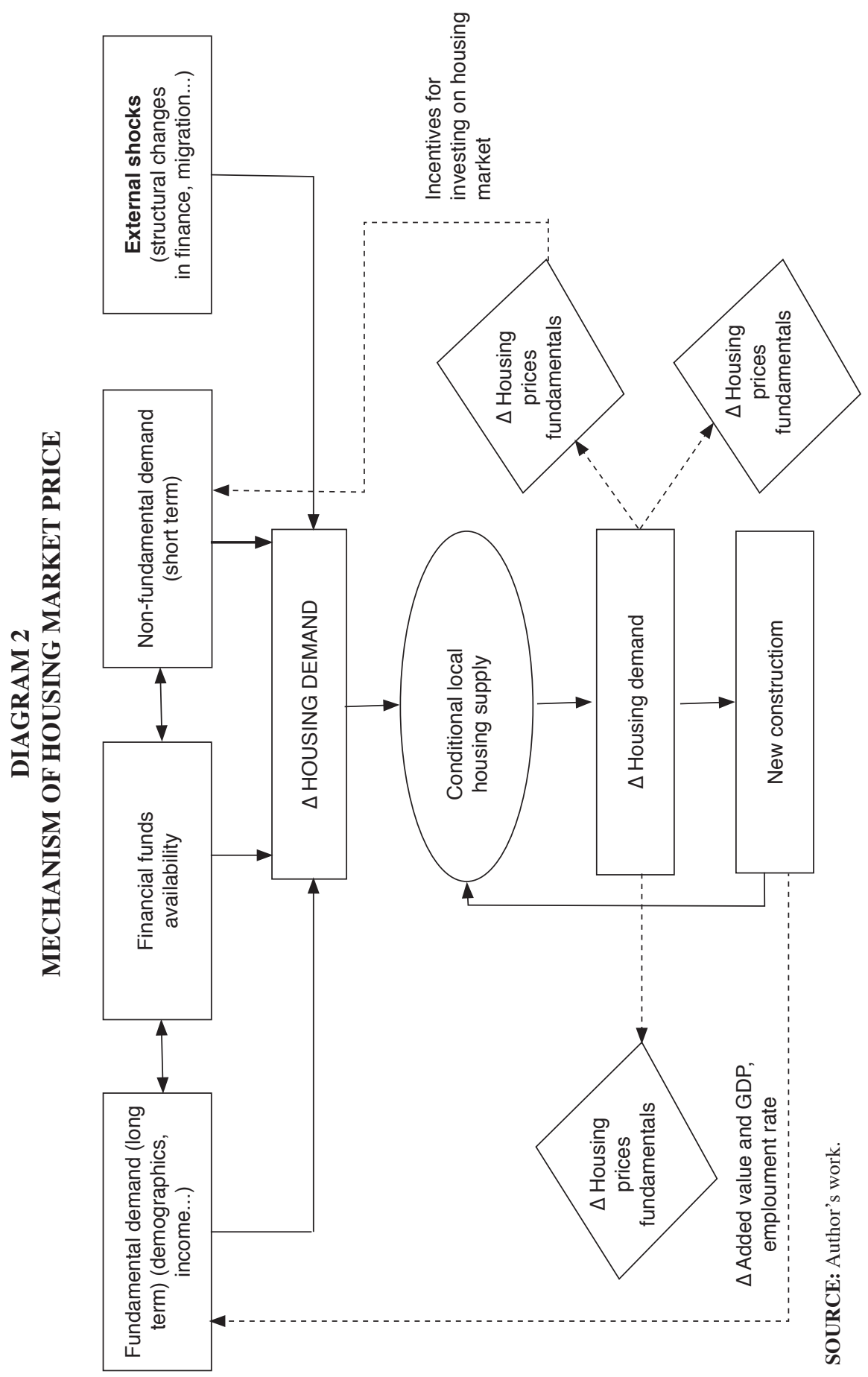


Such a mechanism exists at the aggregate level but also with an initial impact in local markets. The literature finds long run equilibrium processes are established for housing markets (between house prices and macroeconomic variables). In addition there is a particular focus on short run dynamics of adjustment processes in housing market research. From a microeconomic perspective, house prices are the result of local short run disequilibrium, with the housing market showing an imperfect equilibrium due to inflexible supply and the difficulty in responding to demand change (DiPasquale and Wheaton, 1994; Ortalo-Magné and Rady, 2006). The literature discusses inflexibility of supply (Muellbauer and Murphy, 2008), reflecting the fact that housing market equilibrium does not take place in the short run because of the rigidity of the supply curve. Equilibrium is eventually achieved as the curve gradually acquires more flexibility and adjustment takes place (Meen, 2002, Topel and Rosen, 1988; Quigley, 1997; De Leeuw and Ekanem, 1971; Olsen, 1987; Hanushek and Quigley, 1979; Meen, 2002; Blackley, 1999; Glaeser et al., 2005).

High house prices generated by endogenous mechanisms are related to social imbalances. In many countries, lack of housing affordability arises when house prices have increased faster than incomes. In addition, the loss of employment means a fall in the capacity to repay mortgages and consequently an increase in delinquency and evictions raising the number of repossessions. Lack of affordability affects household formation with permanent consequences for society and social inequality.

The seminal sociological analysis of the role of the housing market in social inequality stems from Rex and Moore's (1967) analysis in the UK. Subsequently several studies have found that the housing market generates inequalities that cross-cut those of the labour market. Murie and Musterd (1996) indicated that in the long term, polarisation in income results in a polarised housing market and social segregation, which is locally contingent. This in turn reinforces the divergence emerging from the labour market and wider macroeconomic imbalances. The dysfunction in housing markets manifests itself primarily through income polarisation principally via transferred housing cost impositions on the household's remaining residual income to the population strata in the low to moderate income bands. Frick and Grabka (2003) indicate that there are significant income advantages derived from owneroccupied housing. Their impact on personal income distribution generates distinct cross-national differences which increases income inequality between groups of owner-occupiers and renters.

\section{The role of credit as a demand driver in housing markets}

As the housing market becomes more owner-occupied in developed countries (and streams income and wealth effects into the economy), the need to identify the role of credits flows as a house price determinant, has increased in significance. As credit flows increase in importance as demand side factors in owner-occupied 
markets, it also brings finance market influences into the housing market, including imbalances and creating (first time tested) multiplier effects which significantly impact on the housing market mechanism, increasing the house price reaction in the presence of financial liberalization. Many studies (e.g., Muellbauer, 2007; Goodhart and Hofmann, 2008) support the idea that close coordination between housing and mortgage markets has developed an accelerator mechanism (for both) and house prices have become a driver affecting monetary liquidity, inflation and financial distress. Recent literature gives empirical evidence of these imbalances.

It is generally believed that mortgage credit is exogenously determined through the credit channel and its marginal effect on house price is captured by interest rates (see Mishkin (2007) and Muellbauer (2007)). Levitin and Wachter (2013) consider that housing is unusually susceptible to booms and busts because the credit conditions affect demand as home-ownership usually requires borrowing making the housing market dependent on the credit system. As a result of exogeneity and the need for mortgages, any imbalance in the credit system is transmitted through an increase/decrease in financial flows to the housing market. The credit channel of the monetary transmission framework explains how mortgage flows incentive housing construction and prices in one direction (as explained below). However there could also be an endogenous component to mortgage liquidity which increases when house prices are rising, consistent with there being moral hazard in mortgage markets (Muellbauer, 2007).

The effect of credit in housing markets is not only due to the increase in affordability to buy a house. The seminal analysis of Case et al. (2003) defended the existence of a wealth effect in housing markets. The wealth effect reflects an increase in general consumption following the perception of higher wealth associated with owner-occupied housing. The wealth effect clearly appears in a housing market due to homeowners withdrawing remaining housing equity and/or asking for a mortgage increase and using it for consumption.

Expectations (both forward and backward looking) are also relevant in explaining the wealth effect because homeowners do not seem to consider fundamental value in tenure choice decisions. Following behavioural interpretations (Shiller, 2007), if prices have been increasing homeowners expect prices to keep on rising. Thus their price expectations are affected by recent price movements. They may therefore have adaptive or even myopic expectations processes. These are purely backward looking at the history of house price evolution itself. No consideration is given to exogenous factors driving house prices and no expectation of the future path of those factors is formed. Case et al. (2003) suggest that such «expectations may contribute to the substantial swings that are observed in housing prices» (p. 149). They further argue that housing wealth effects can impact on the economy via consumers' expenditure, especially if the wealth effect is perceived to be permanent. Over an economic cycle, in a recession period after house prices have been observed to have fallen, there may be expectations of further falls or no growth. Losses, real or perceived would then negatively impact the wealth effect, consumers' expenditure, and GDP growth. 
Towards the market peak, the reverse set of expectations and consequent behaviours would be in operation.

Earlier studies for example, by Shiller (2000) focused on how the deregulation of the financial system at the global level contributed to large flows of liquidity. Most of the effects of financial liberalisation were transmitted via the banking system, with the increase in liquidity and credit having an impact on both private and public debt. This resulted in high levels of indebtedness of households and firms (Debelle, 2004, Iacoviello and Minetti, 2008). In the case of households, one of the effects of financial liberalisation was an increase in finance flows towards housing and real estate markets, creating the first synchronised global housing cycle (Taylor, 2007, Kim and Renaud, 2009). Indeed, a wealth of recent literature (Mishkin, 2007, Muellbauer, 2008, Iacoviello, 2005) demonstrates that increases in mortgage credit resulting from monetary policy fuelled housing demand and increased house prices (Bernanke, 2010).

Considering credit channel effects, there is also recent literature analysing how house prices could affect monetary policy goals and how it creates new interrelationships between monetary liquidity and house price dynamics. It is a combined mechanism: Monetary liquidity affects credit generation by fuelling housing demand and thus causing house prices to rise (Lastrapes, 2002, Aron et al, 2010, Goodhart and Hofmann, 2008). As the number of loans (to housing) increase, the credit multiplier increases liquidity in the economy which effects monetary policy goals.

However, few studies have investigated the links between monetary policy and housing booms (Mishkin, 1995, 2007, Favero and Giavazzi, 1999) supporting the idea that the credit channel is not the only way to transmit the effect of house price changes. Muellbauer (2007), Setzer et al. (2010) and Greiber and Setzer, (2007) find evidence that liquidity contributes to an increase in house prices, through three different channels: money demand (Setzer et al 2010, Friedman 1988), asset inflation (the role of liquidity with respect to housing finance), as well as credit channels. They conclude that housing may act as a catalyst which amplifies the effects of monetary policy reinforcing the relationship between house prices and loans and providing a house price channel. They find that «...collateral or credit channel effects which also imply a positive correlation between money and housing should be significant. This is in line with empirical estimates suggesting that house price fluctuations are a major determinant of credit cycles (ECB 2003)». (Greiber and Setzer, 2007:15). 


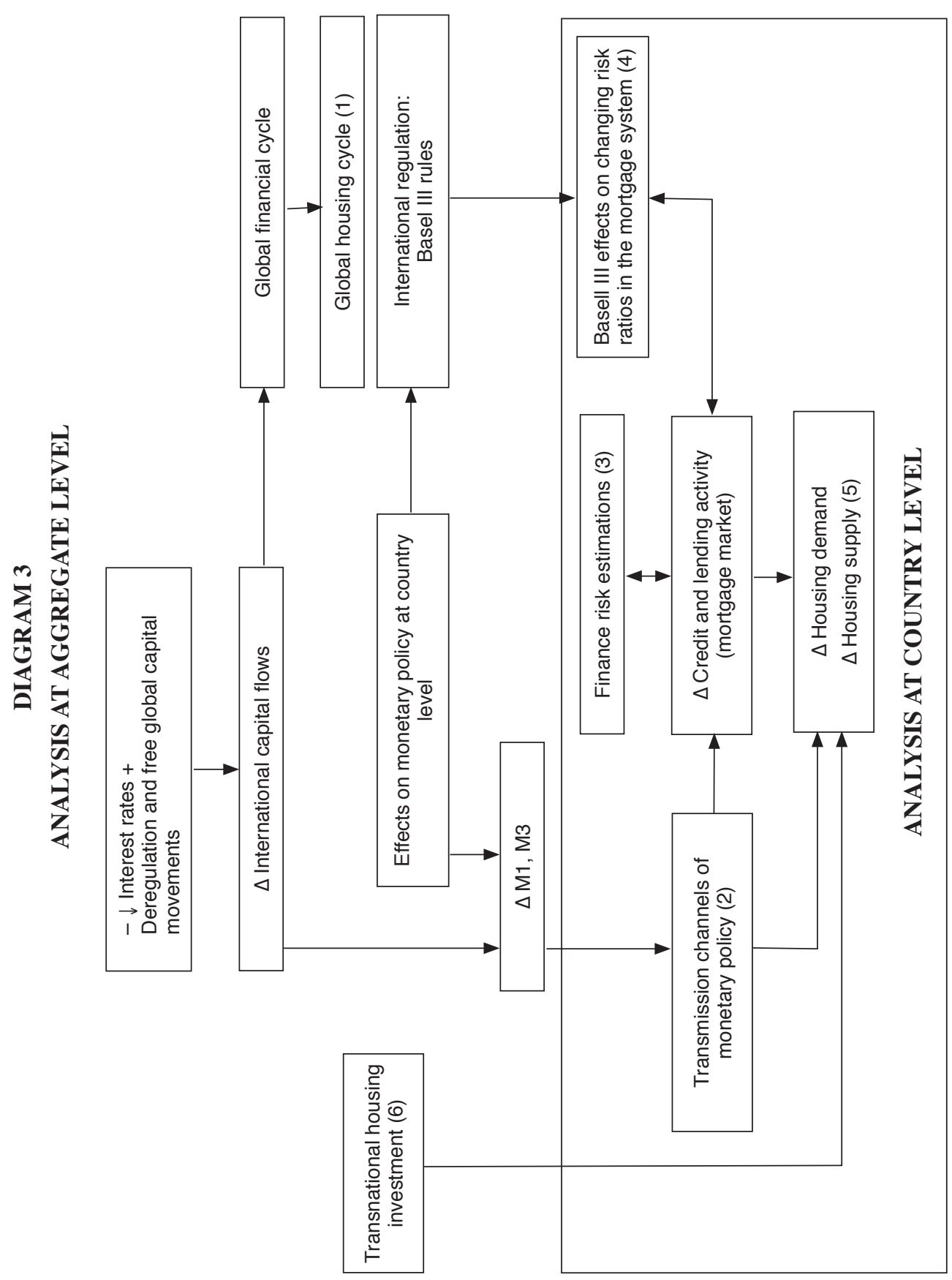


The essence of this literature is summarised in diagram 3 and distinguishes between capital/monetary flows and financial flows. The former have indirect effects on house prices through channels of monetary transmission while the financial cycle affects housing through direct investment or financing developments.

Credit supply elasticity can be considered to depend upon financial regulation. Currently, there is little analysis in the literature about how the Basel II and III regulations have affected lending activity though it seems probable that any impact in the credit sector will also impact the housing sector. Furthermore, any imbalance in the credit sector, as well as new regulation, will have social effects on the homeownership market which must be investigated.

\section{Transmission channels}

This section is devoted to explain in detail the transmission channels of monetary policy affecting housing prices which the literature has highlighted. Three channels are explained here which identify the direction of influence and define the housing channel multiplier: credit, asset and money demand channels.

The credit channel is activated when the availability of mortgage finance supports demand for owner-occupation. This is because households rarely have sufficient equity for house purchase without recourse to debt financing. This argument is especially relevant in those markets with high ownership rates. Thus mortgage credit is a critical component in housing owner-occupied demand. The causal relationship is explained below:

The credit channel identifies the impulse of credit flows initiated from a monetary policy intervention:

$$
\Delta M \Rightarrow \Delta \text { bank deposits } \Rightarrow \Delta \text { bank loans } \Rightarrow \Delta \text { Debt } \Rightarrow \Delta l \Rightarrow \Delta Y
$$

As debt flows are oriented to the housing market both credit channel and transactions effect (Stein, 1995) impact house prices:

$$
\begin{aligned}
& \Delta \text { Debt }+ \text { equity } \Rightarrow \Delta \text { housing purchase capacity } \Rightarrow \\
& \Rightarrow \Delta \text { Effective housing demand (transactions) } \Rightarrow \Delta P_{h} \mid \varepsilon \text { of supply }
\end{aligned}
$$

Where $\varepsilon$ is the elasticity of supply in each market and $M$ is base money supply, $I$, investment, $Y$ is final GDP and $P_{h}$ is house prices. $\Delta$ refers to changes.

Once the increase in house prices has happened, the wealth effect called the «housing collateral effect» (Muellbauer, 2007) operates through the withdrawal of housing equity by homeowners. The mechanism starts both, when there is a rise in house prices or when the house value increases equity in the householders' budgets. The overvaluation increases the collateral value and allows owners to increase debt 
based upon it. In this process the increase in liquidity of housing wealth allows homeowners to expand their consumption.

$$
\Delta P_{h} \Rightarrow \Delta \text { collateral value } \Rightarrow \Delta \text { Debt }
$$

The flow of funds into mortgage markets is determined by the financial system, which is regarded as being exogenous. The collateral effect in the literature contradicts the view that the total value of mortgages is determined exogenously to the housing market and alternatively posits that there is an endogenous component causing mortgages to increase when house prices are rising, consistent with the hypothesis of moral hazard in the mortgage market (Muellbauer, 2007). This means double directional causality inside the credit channel.

Wealth effects occur due to the existence of the credit channel but, following Mishkin (1995), the classical wealth effect on consumption implicit in the life-cyclepermanent income theory (Modigliani) also appears to be operating through the propensity to consume, which does not require the credit channel ${ }^{3}$. That is:

$$
\begin{aligned}
\Delta P_{h} & \Rightarrow \Delta \text { collateral value } \Rightarrow \Delta \text { Debt } \Rightarrow \Delta \text { liquidity of housing wealth } \Rightarrow \\
& \Rightarrow \Delta \text { Consumption }
\end{aligned}
$$

Spreading out the effect of an increase in house prices to the economy potentially induces imbalances which take the form of excess consumption far above purchase capacity, or excessive debt to finance houses and other consumption goods. This is known as the House Price Channel (Muelbauer, 2007; Setzer et al., 2010; Greiber and Setzer, 2007).

A second channel of transmission recognized to affect house prices is the «Asset Inflation Channel». It measures how the potential effects of an expansionary monetary policy providing ample liquidity to the markets may trigger a rebalancing of assets and thus cause house price increases. It can be explained as follows:

$$
\begin{aligned}
\Delta \mathrm{M} & \Rightarrow \Delta \mathrm{CPI} \text { or } \Delta \text { Asset Price } \\
& \Rightarrow \text { when supply elastic of } C \text { goods }>1 \Rightarrow \Delta \mathrm{Pcpi} \rightarrow 0 \text { (goods competition) } \\
& \Rightarrow \text { when supply elast of Assets }<1 \Rightarrow \Delta \text { Passet } \rightarrow 1
\end{aligned}
$$

(As housing market has restricted supply)

Then

$$
\begin{aligned}
\Delta \mathrm{M} \Rightarrow \Delta \mathrm{CPI} * \varepsilon_{\text {supply }} \text { or } \Delta \text { Asset Price } * \varepsilon_{\text {supply }} & \Rightarrow \text { inflation } * \varepsilon_{\text {supply }} \text { or } \mathrm{P}_{\mathrm{h}} * \varepsilon_{\text {supply }} \Rightarrow \\
& \Rightarrow \Delta \mathrm{P}_{\mathrm{h}}
\end{aligned}
$$

${ }^{3}$ MUELLBAUER (2007) maintains that, in absence of the credit channel, the wealth effect could be, simply, non existent or be negative 
An increase in real house prices (relative to consumer goods) is the result of differing price elasticities of supply and the impossibility to increase consumer prices (because of strong competition and low cost production) in response to a liquidity shock. With decreasing inflation, people underestimate future real payments related to their loans increasing demand and borrowing for housing.

In the asset inflation channel, changes in money supply lead to changes in inflation or asset prices with the final effect depending upon the price elasticity of goods and assets. If goods have a high supply elasticity, price changes will tend towards zero. Conversely where supply elasticity is price inelastic as in the housing market, there will be asset price inflation. The supply of houses is assumed to depend upon the price of houses, construction costs that reflect land and labour costs, and the impact of planning systems, that is, mostly variables relating to the housing market that are far removed from financial factors.

Changing house prices cause changes in the relative attractiveness of different assets leading to changes in housing and money demand and changes in the proportion of property held in investment portfolios. Changes in transactions (by house prices and the number of transactions changing) lead to changes in money demand for payments which are higher in boom periods leading to a need for more deposits and liquidity.

Both channels transmit influences between the housing and financial markets, liquidity and the rest of the economy potentially generating imbalances at every level, including monetary policy.

Mishkin (1995, p. 7) argues that «dissatisfaction with... conventional stories about how interest rate effects explain the impact of monetary policy on expenditure on long-lived assets has led to a new view of the monetary transmission mechanism that emphasizes how asymmetric information and costly enforcement of contracts creates agency problems in financial markets». He identifies a «bank lending» channel and a «balance sheet channel» through which transmission occurs. Contractionary monetary policy will reduce the availability of bank loans to households that will in turn reduce asset prices. Via the balance sheet channel, the lower value of assets translates into lower net worth, raising perceived risks and further reducing lending and liquidity in the market.

Research has suggested that house price rises have caused lending to increase from the financial sector (e.g., via a balance sheet effect where there is perceived higher net worth and less risk). The housing wealth effect has also added to consumption, stimulating aggregate demand. Any increase in lending for house purchase causes an increase in effective demand, affecting housing prices. Theoretically, in a mainly homeowner market an increase in lending induces upward pressure on house prices but more empirical evidence is needed to know the size and direction of the house price and mortgage debt effect as it is not obvious and hence it is necessary to analyse how house prices react in any given market.

Note that both channels have a final impact on monetary liquidity. In the credit channel change in the price of housing causes changes in lending volumes which 
generate further increases in monetary liquidity through the credit multiplier. Higher collateral tends to improve lending conditions and raises liquidity through the transaction effect (Stein, 1995). This tends to have a positive impact on money supply. As this channel is bidirectional it is identified as an accelerator as in Greiber and Setzer (2007) and considered to affect monetary policy goals. Further, Elbourne (2008) suggests that housing wealth affects consumption while Setzer et al. (2010) suggest that housing wealth also affects demand for money.

Lastrapes (2002) analysed the response of owner-occupied house prices to money supply shocks. He identified the effect of a money supply shock and found that monetary shocks have real effects on the housing market, in relation to both prices and housing sales volumes (for both new starts and existing homes), which rise in the short-run in response to positive shocks to the money supply. He demonstrated that there were two channels through which money supply shocks could affect the housing market: first by affecting the relative cost of housing finance (interest rates) and second through the real rate of return of housing (the asset inflation channel). The total impact varied between different housing markets due to differences in supply responsiveness.

Financial deregulation and competition made access to the debt market easier for many households. If house prices are rising there is an economic incentive to enter the owner-occupied housing market to make a capital gain and develop the circle- house price channel- between credit and house prices. Access to credit and the ability to borrow relatively high loan-to-value ratios is converted into increased capital values and in the short term, given supply inelasticity and with adaptive expectations, the expectation of further price increases. This bubble is burst when the first signs of default emerge. This triggers a reversal in the behaviour of lenders and subsequently expectations of borrowers and potential house purchasers. In addition, expansionary monetary intervention can also accelerate the circle, potentially, creating new bubbles conditional on local market conditions ${ }^{4}$. The cases of some large housing markets experiencing house prices rising after the GFC (like London or Berlin) illustrates these effects.

\section{Summarising the imbalances}

Most literature explaining house pricing and market disequilibrium focuses on identification of the role of fundamentals in determining the price effects; other studies looks for bubble determinants and identify them capturing the role of financial variables in house price evolution and the detection of imbalances. The latter literature is not large enough but it has identified the role of transmission channels in house price evolution. What is agreed is that housing market instability generates macroeconomic imbalances.

${ }^{4}$ Little empirical work has study the monetary and liquidity effects. One analysing Spain and UK is TALTAVULL DE LA PAZ and WHITE (2012). 
Real variables create an imbalance when they perform out of their long term equilibrium, for example when there is a fall in production, changes in demand (increases or decreases), exports/imports, either at unusually high or low levels, produce international imbalances. Similarly, imbalances occur with large changes in population mobility and migration flows. Financial or monetary imbalances appear when long term inflation occurs or when financial flows change affecting investment (real). Four groups of factors emerge as being important: (1) real factors with permanent effects for any economy, such as growth/fall in demand due to changes in domestic demographic structure, income or long term economic growth determining the wealth accumulation process in the economy (2) financial factors including funds and interest rates, which are both directly determined by the total availability of domestic funds in the economy and by private and public savings, and by the degree of integration in the international financial system allowing use of extra savings from other economies. Collectively groups (1) and (2) have long term effects on the economy. (3) Short term variables affecting the macroeconomy equilibrium, for example movements in interest rates or inflation and (4) shocks occurring in the economy due to unexpected and unforeseeable changes in some economic and social conditions form the third and fourth groups respectively.

Imbalances at a macroeconomic and a housing market level can be categorized as diagram 4 shows. It summarizes the potential imbalances the literature identifies associated with the housing market mechanism and through prices and development mentioned above. There are three main paths by which housing dynamics generate imbalances in the economy: The first is the endogenous way, which is the one impacting at a local level and through the real effects on housing markets; the second is the aggregate imbalances which is produced by the spillover effects coming from local imbalances in the presence of specific conditions in the financial market. Those effects on financial as well as monetary markets have imbalances due to exogenous factors. The third path is the one generated by external shocks transmitted to the local economy. 


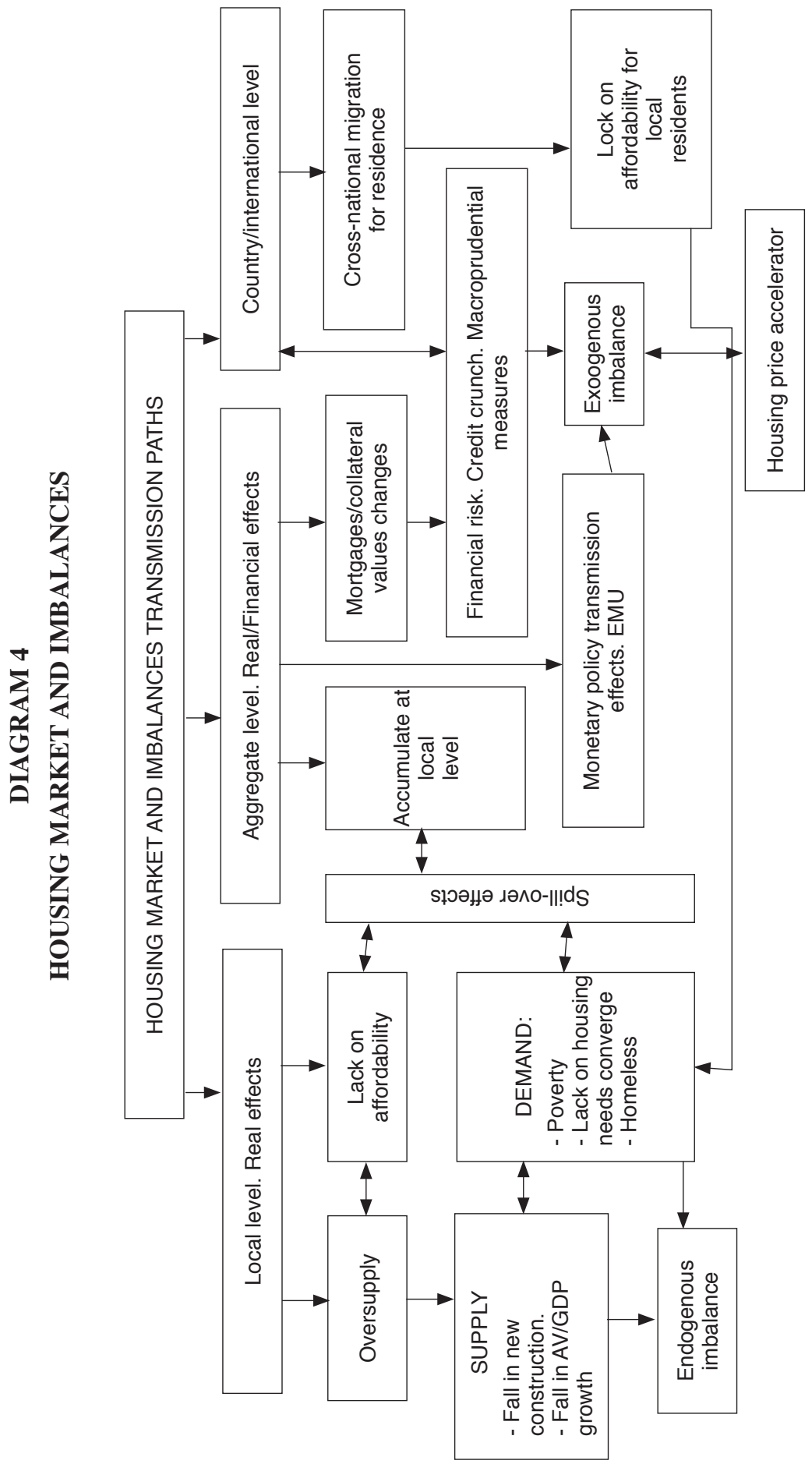


The literature lends support to the argument that the main imbalances in macroeconomies directly affect and are affected by how housing markets perform. The relevant role played by house prices (housing market signal) has been considered to have had a strong influence in economic imbalances. This is why the EU (EU, 2012:16) ${ }^{5}$ includes house price indexes as one of the 14 main indicators to classify economic imbalances. Such inclusion is also justified by literature at an international level which places strong emphasis on this macro relationship (Levitin and Wachter, 2013).

Research by Iacoviello and Neri (2010) examines spillovers between the housing market and the wider economy. They argue that monetary variables affect house prices and that house prices have an impact on consumers' expenditure. BaffoeBonnie (1998) suggested that macroeconomic shocks affect the housing market. Demary (2010) applied the econometric technique of vector autoregressive modelling to examine the relationship between house prices and the macroeconomy across 10 countries. He found that house prices were negatively related to inflation and interest rate shocks. In addition he found support for a housing wealth effect and links house price shocks and interest rates.

The second way has been substantially documented by many studies. Goodhart and Hofmann (2008) stated that «... many industrialised countries have experienced extraordinarily strong rates of money and credit growth accompanied by strong increases in house prices» (p. 180). As a consequence of this price inflation, housing became a more attractive asset for investors. As an asset it would also generate a stream of expected returns. Financial deregulation and the availability of debt finance enabled investors to purchase more housing assets. Wealth effects of higher asset values also fed into consumption resulting in GDP growth. Yet as house prices rose, not only were houses in demand as a consumption good for the flow of «housing services» they provide, but they were also in demand from investors who were interested in the relatively high capital and income returns that could be made (e.g., buy-to-let investment has been a particular feature in the UK and Ireland) «While the housing wealth and housing collateral effects on consumption are the most important or most explored channels of the transmission of house-price fluctuations to the real economy, the transmission via private investment also plays a role» (op. cit., p. 182) The period before 2007 saw an increase in buy-to-let investment. The capital gains could help to cover lower income returns due to void periods.

Greiber and Setzer (2007) examined the relationship between money and housing variables in the Euro area. They found evidence that liquidity contributed to increases in house prices, through three different channels: money demand, asset price, and credit channels. The opposite direction of causality has also been tested. Setzer et al, (2010) estimated money demand and included real house prices as an explanatory variable in their model. They found that housing wealth as captured by house prices has been a significant determinant of money holding

5 EUROPEAN ECONOMY (2012). «Scoreboard for the surveillance of macroeconomic imbalances», Occasional Papers 92, February 
since 1999. They also find evidence that the role of housing became stronger after adoption of the single currency in 1999. Previously, there had been a closer relationship between local income and house prices with a limited role for cross border capital flows.

Aspachs-Bracos and Rabanal (2009) concluded that none of the monetary shocks, neither the interest rate shock nor the risk premium shock, played a significant role in explaining the housing boom in Spain. Monetary policy action only affected housing prices when interest rates increased from $2 \%$ to $4 \%$ while Taltavull de La Paz and White (2012) demonstrated that the role of liquidity exists but is stronger in the UK than in Spain, operating through the credit channel with a direct impact on house prices.

\section{Discussion}

Increased integration of capital markets, greater access to credit markets and role of housing as an investment have changed the nature of housing as an asset and its relationship with the macroeconomy. As housing is mainly debt financed, developments in the mortgage market might be expected to have a significant impact on mortgage market liquidity flows. Therefore studies on housing markets and the evolution of house prices need to carefully consider the role played by the mortgage market. In Europe, between 2001 and 2008 mortgage debts rose as a percentage of GDP in all countries except Germany, ranging from 20\% of GDP in Italy to $130 \%$ in Iceland (Meen, 2011). In Ireland the ratio increased from 33\% to $80 \%$ over this seven year period.

The stock of debt to household disposable income has also shown an increasing trend. Meen's (2011) «results indicate that the ability of existing owners to increase housing demand by re-investing equity leads to an increase in the income and interest rate elasticities of house prices. Furthermore, since the debt/income ratio increases over time if the income elasticity of demand exceeds the price elasticity, households become more vulnerable to adverse shocks to income or interest rates, which have larger effects on house prices. Under this story, expectations are not driving volatility, although these may also be an additional factor. Furthermore, because of the longrun nature of the mortgage contract, households cannot easily respond to adverse shocks by running down debt» (p. 271).

The role played by mortgage markets has perhaps been under-researched in the literature. The papers above are some of the few since the beginning of the financial crisis that have begun to shed some light on this area. While mortgage contract design is beyond the scope of this current paper, the exposure of the UK market to variable rate mortgage contracts and the absence of long term fixed rate mortgages makes the UK market more sensitive to changes in interest rates and therefore potentially more volatile than if a larger proportion of mortgage payments were fixed for long time horizons. This then adds extra volatility to the macroeconomy and makes the 
use of interest rates more difficult for policy makers, constraining monetary policy choices.

The exposure of the mortgage market to liquidity coming from securitization is argued to have provided additional funds for lending. However this is not been without risk as was evidenced in the problems originating in the sub prime market before 2007.

\section{Conclusions}

This paper contains a summary of the literature to frame and understand the reasons why the EU regulations of the Macroeconomic Imbalance Procedure (MIP) and the Excessive Imbalance Procedure (EIP) includes changes in house prices as one of the 11 indicators of economic imbalances. It also discusses whether or not that indicator needs to be complemented to follow housing market dynamics. The paper explains how the housing mechanism is related to real as well as financial markets and how, through the channels of transmission, house prices define the house price channel linking financial shocks with real shocks and creating imbalances. A classification of imbalances is also provided as the summary of the literature.

Housing markets are strongly linked with the macroeconomy. House prices move pro cyclically and usually with greater amplitude of fluctuation than the economy itself.

Shocks to the housing market have been internationally correlated for the first time during the credit crunch that was sparked by the sub prime crisis in the USA. Hence the role of liquidity has high significance and is seen in results above from research particularly on the UK housing market. Because access to debt finance can stimulate house prices, against a background of low supply elasticity, homeownership becomes increasingly difficult for younger age groups. Levels of homeownership for younger age groups (under 40 years old) have been falling in the US, UK, Australia and Denmark. This age group has been disadvantaged by rising house prices that have tended to benefit older generations. In addition demographic change has also impacted on housing demand putting upward pressure on prices in the market in Spain. However the continuing exposure to debt finance, as houses are usually bought with mortgages, together with changes in ability to access debt markets may imply that future house price volatility may be inevitable.

The house price channel discussed above suggests that housing may reinforce monetary policy changes. The credit channel focuses on the impact that changing monetary policy can have via bank deposit and bank loan volumes changing. A further link is provided between housing and the macroeconomy via collateral or wealth effects such that as house prices rise homeowners feel wealthier and increase consumers' expenditure either from their labour incomes, reduce savings, or borrow against accrued housing wealth (value). The latter is aided in financial systems that permit such borrowing to occur. Expectations of continuing house price rises 
may then feed into increased consumer spending. The opposite would happen in recessions. Thus the channels connecting the housing market and macroeconomy could further increase macroeconomic instability and volatility.

Given the complexity in the housing market relationship, one remaining thought is that house price dynamics, alone, cannot prove the existence/inexistence of an economic imbalance. Some markets could experience continuous house price increase without be imbalanced. Signals of house-price change have to be found in demand forces and supply responses. The key indicators of demand and supply could be affordability and supply elasticity which could be good reasons why house prices should be added as complementary indicators in the EIP mechanism.

This paper also highlights how different mechanisms of house price formation, both coming from fundamental demand flows and/or from the «perception-expectations» of future price evolution affecting investment and credit flows, could constitute an imbalance in an economy. Several variables affecting housing prices could be in equilibrium/disequilibrium with other economic factors but at the same time not imply a balanced macroeconomic growth path. It is therefore relevant to identify the reasons why house prices evolve in order to understand the «momentum» when there are changes in exogenous factors so that precise measures of housing policy can be enacted and/or any imbalance can be identified.

\section{References}

[1] ARON, J.; DUCA, J.; MUELLBAUER, J.; MURATA, K. and MURPHY, A. (2010). «Credit, Housing Collateral and Consumption: Evidence from the UK, Japan, and the USA». Department of Economics Discussion Paper, Oxford.

[2] ASPACHS-BRACONS, O. and RABANAL, P. (2009). «The Drivers of Housing Cycles in Spain», IMF Working Paper, WP/09/203.

[3] BAFFOE-BONNIE, J. (1998). «The dynamic impact of macroeconomic aggregates on housing prices and stock of housing: A national and regional analysis». Journal of Real Estate Finance and Economics, 17 (2), 189-216.

[4] BLACKLEY, D. M. (1999). «The Long-Run Elasticity of New Housing Supply in the United States: Empirical Evidence for 1950 to 1994». Journal of Real Estate Finance and Economics, 18 (1), 25-42.

[5] BERNANKE, B. S. (2010). «Monetary Policy and the Housing Bubble, Speech on Annual Meeting of the American Economic Association». Available in $h t t p: / / w w w . f e d e r a l r e s e r v e$. gov/newsevents/speech/bernanke20100103a.htm?sourc (access 10/04/2012).

[6] CASE, K. E. and QUIGLEY, J. M. (2008). «How housing booms unwind: Income effects, wealth effects, and feedbacks through financial markets». European Journal of Housing Policy, 8 (2), 161-180.

[7] CASE, K. E.; QUIGLEY, J. M. and SHILLER, R. J. (2003). Home-buyers, housing and the macroeconomy. Federal Reserve Bank of Australia.

[8] DE LEEUW, F. and EKANEM, N. F. (1971). «The Supply of Rental Housing». The American Economic Review, 61, 806-817. 
[9] DEBELLE, G. (2004). «Household debt and the macroeconomy». BIS Quarterly Review, pp. 51-64.

[10] DEMARY, M. (2010). «The interplay between output, inflation, interest rates and house prices: international evidence». Journal of Property Research, 27 (1), 1-17.

[11] DIPASQUALE, D. and WHEATON, W. (1994). «Housing market dynamics and the future of housing prices», Journal of Urban Economics, 35, 1-28.

[12] DIPASQUALE, D. y WHEATON, W. (1996). Urban Economics and real estate markets. New Jersey. Prentice-Hall.

[13] ELBOURNE,A. (2008). «The UK housing market and the monetary policy transmission mechanism: An SVAR approach». Journal of Housing Economics, 17, 65-87.

[14] EUROPEAN ECONOMY-EU (2012). «Scoreboard for the surveillance of macroeconomic imbalances». Occasional Papers 92, February.

[15] FAVERO, C. A. and GIAVAZZI, F. (1999). «An evaluation of monetary policy transmission in the context of the European Central Bank». Report to European Parlament. Available at http://didattica.unibocconi.it/mypage/upload/48917_20081009_105606_ IGIER_FAVERO_STRASBOURG-FG.PDF (access 10/4/2012).

[16] FRICK, J. R. and GRABKA, M. M. (2003). «Imputed rent and income inequality: A decomposition analysis for Great Britain, West Germany and the US». Review of Income and Wealth, 49 (4), 513-537.

[17] FRIEDMAN, M. (1988). «Money and the Stock Market». Journal of Political Economy, 96 (2), 221-245.

[18] GLAESER, E. L.; GYOURKO, J. and SAKS, R. E. (2005). «Urban Growth and Housing Supply». HIER Discussion Paper No. 2,062, SSRN papers series No. 658343. Available at $h$ ttp://ssrn.com/abstract $=658343$.

[19] GOODHART, C. and HOFMANN, B. (2008). «House prices, money, credit, and the macroeconomy». Oxford Review of Economic Policy, 24 (1), 180-205.

[20] GREIBER, C. and SETZER, R. (2007). «Money and housing -evidence for the euro area and the US». Discussion Paper Series 1: Economic Studies, Eurosystem No. 12/2007

[21] HANUSHEK, E. A. and QUIGLEY, J. M. (1979). «The Dynamics of the Housing Market: A Stock Adjustment Model of Housing Consumption». Journal of Urban Economics, 6 (1), 90-111.

[22] HIMMELBERG, C.; MAYER, C. and SINAI, T. (2005). «Assessing high house prices: Bubbles, fundamentals and misperceptions». Journal of Economic Perspectives, 19 (4), 67-92.

[23] IACOVIELLO, M. (2005). «House prices, borrowing constraints, and monetary policy in the business cycle». American Economic Review, 739-764.

[24] IACOVIELLO, M. and MINETTI, R. (2008). «The credit channel of monetary policy: Evidence from the housing market». Journal of Macroeconomics, 30 (1), 69-96.

[25] IACOVIELLO, M. and NERI, S. (2010). «Housing market spillovers: Evidence from an estimated DSGE model». American Economic Journal, 2 (2), 125-164.

[26] KIM, K. H. and RENAUD, B. (2009). «The global house price boom and its unwinding: an analysis and a commentary». Housing Studies, 24(1), 7-24.

[27] LASTRAPES, W. (2002). «The real price of housing and money supply shocks: Time series evidence and theoretical simulations». Journal of Housing Economics, 11(1), 40-74.

[28] LEVITIN, A. and WACHTER, S. M. (2013). «Why Housing?». Housing Policy Debate, $23(1), 5-27$ 
[29] MEEN, G. (2002). «An Overview of Issues in Housing Modelling and Policy». The University of Reading Paper Series. November.

[30] MEEN, G. (2011). «The economic consequences of mortgage debt». Journal of Housing and the Built Environment, 26, 263-276.

[31] MISHKIN, F. (1995). «Symposium on the monetary transmission mechanism». Journal of Economic Perspectives, 9 (4), 3-10.

[32] MISHKIN, F. (2007). Housing and the Monetary Transmission Mechanism. Federal Reserve Bank of Kansas City.

[33] MUELLER, G. R. (1999). «Real Estate Rental Growth Rates at Different Points in the Physical Market Cycle». Journal of Real Estate Research, 18 (1), 131-150.

[34] MUELLBAUER, J. (2007). «Housing, Credit and consumer Expenditure». Working Paper Nuffield College.

[35] MUELlBAUER, J. (2008). «Housing, Credit and consumer Expenditure, Centre for Economic Policy Research». Available at http://www.kc.frb.org/publicat/sympos/2007/ 2007.09.17.Muellbauer.pdf (accessed on 01/03/2013).

[36] MUELLBAUER, J. and MURPHY, A. (2008). «Housing markets and the economy: the assessment». Oxford Review of Economic Policy, 24 (1), 1-33.

[37] MURIE, A. and MUSTERD, S. (1996). «Social Segregation, Housing Tenure and Social Change in Dutch Cities in the Late 1980s». Urban Studies, 33 (3), 495-516.

[38] OLSEN, E. O. (1987). «The Demand and Supply of Housing Service: A Critical Survey of the Empirical Literature», in E. E. MILLS, Handbook of Regional and Urban Economics. Amsterdam, North-Holland Vol. II, Chap.25, pp. 989-1022.

[39] ORTALO-MAGNÉ, F. and RADY, S. (2006). «Housing market dynamics: On the contribution of income shocks and credit constraints». The Review of Economic Studies, 73 (2), 459-485.

[40] QUIGLEY, J. M. (1997). The Economics of Housing, Edward Elgar Publishing, Massachusetts. Vols. 1 and 2

[41] REX, J. and MOORE, R. (1967). Race, Community and Conflict. Oxford: Oxford University Press.

[42] SETZER, R.; VAN DEN NOORD, P. and GUNTRAM B. (2010). Heterogeneity in money holdings across euro area countries: the role of housing. European Commission, Directorate General for Economic and Financial Affairs, February.

[43] SHILLER, R. J. (2000, 2007). Irrational Exuberance. Princeton Univ. Press, New Jersey.

[44] SHILLER, R. J. (2007). «Understanding recent trends in house prices and home ownership». (No. w13553). National Bureau of Economic Research.

[45] TALTAVULL DE LA PAZ, P. and WHITE, M. (2012). «Fundamental drivers of house price change: the role of money, mortgages, and migration in Spain and the United Kingdom». Journal of Property Research, 29(4), 341-367.

[46] TAYLOR, J. B. (2007). «Housing and monetary policy» (No. w13682). National Bureau of Economic Research. Available at ftp://ftp.repec.org/opt/ReDIF/RePEc/sip/07-003. $p d f$ (accessed on 13.04.2013)

[47] TOPEL, R. and ROSEN, S. (1988). «Housing Investment in the United States». Journal of Political Economy, 96 (4), 718-740. 